\title{
The Form and the Meaning of Bridal Dowry in Indonesia
}

\author{
Arita Puspitorini, Rahayu Dewi Soeyono, Mutimmatul Faidah \\ Department of Home Economics \\ Universitas Negeri Surabaya \\ Surabaya, Indonesia \\ aritapuspitorini@unesa.ac.id
}

\begin{abstract}
A bridal dowry as in a procedure of wedding ceremony regarding the specific regions is dependent to that of regions' cultures applied. This research aims to know the form, the function and the meaningfulness of a bridal dowry in Tuban, one of cities in East Java Province, Indonesia. Under a descriptive qualitative approach, the data were collected through interview, observation, and documentation. The research participants involved are the members of Harpi Melati, cultural observers, government tourism officers, and society's prominent figures. Results showed that a bridal dowry refers to a symbol that the groom was able to responsible for any bride's needs. Along with the development of era, many future couples of bridegrooms decided to fill the bridal dowry with some useful goods for daily necessities.
\end{abstract}

Keywords-diverse culture; a bridal dowry; form and meaningfulness

\section{INTRODUCTION}

Indonesia has diverse cultures covering the natural resources and culinary. Every single island has differently unique cultures which can be seen from the indigenous languages, the shapes of the houses, the traditional clothes, the dances, and also the procedures of wedding ceremony. The diversities become a national asset that must be preserved. One of the most preserved ones is the process of marriage proposal in the phase of giving a bridal dowry.

A bridal dowry is an activity of giving things symbolizing a respect given by the groom family to the bride ones for expressing love and responsibility in accommodating all the bride's needs. The dowry might be in the form of anything regarding the cultures applied in the area, the capability of the groom family, and the demands proposed by the bride family. The cultural characteristics of a bridal dowry can be seen from the various form, function, and meaningfulness of each dowry given at the stage of wedding ceremony. This research investigates the form, function, and meaningfulness of a bridal dowry happened in Tuban regency, East Java Province, Indonesia.

In accordance with the administrative issue, East Java Province has 29 regencies and 9 cities in which it makes the province have the most cities and regencies in Indonesia. East Java population, generally, believes in monogamy. Before the proposal, the groom does a kind of tradition called nako'ake (asking the bride whether she has already had the candidate for her husband), then peningsetan, known as a proposal phase is done afterwards [1]. A wedding ceremony begins with a traditional meeting called temu or kepanggih. Societies in the western seaboard of East Java Province such as Tuban, Lamongan, Gresik and Bojonegoro regencies have a common habit where the bride family is the one asking the proposal to the groom family. This is contradictory to what general tradition has in other parts of Indonesia where the groom is the one who asks the proposal.

\section{METHOD}

This descriptive qualitative research has kinds of research participants involving the members of Harpi Melati organization, the chief of local government tourism office, cultural observers, bridegroom makeup artist, and the prominent figures in Tuban. The research took a setting in Tuban regency, East Java Province. Data were collected through interview, observation and documentation using interview guideline, observation sheet, and documentation guideline. Respondent by eight person from senior make up artist. Afterwards, data were analyzed during the data collection processes covering data identification, reduction, and conclusion

\section{RESULTS AND DISCUSSIONS}

\section{A. Profiles of Tuban Regency}

Tuban regency is one of regencies located in the northern beach of East Java Province. Its capital is located in Tuban sub-district and has about 1.3 million people spread in twenty sub-districts. It has various stories beyond the occurrence of the regency. First, Tuban was occurred from watu tiban (stones falling from the sky), a stone heirloom brought by a couple of birds from Majapahit moving into Demak, which was suddenly felt in the area now so-called Tuban [2].

The second version revealed that the regency was from an ancient phenomenon familiarly known as metu banyu, a process that makes the water inside the ground out. Historically, it was due to the fact that Raden Dandang Wacana (Kyai Gede Papringan), respected as the first Regent of Tuban, opened Papringan forests that further resulted a big flood caused by the very swift water coming from the inside ground land. This related to the presence of a shallow old well with the overflow savorless water, in which it is strange due to 
the location nearby the shore. The last version claims a different perspective that Tuban was from a word tuba, similarly to what was known as poison [3].

Tuban is located on the northern coastline and on the mountain range of the North Cretaceous. The Northern Limestone Mountains in Tuban extend from Jatirogo to Widang District, and from Merakurak to Soko Sub-district. Moreover, the sea area lies between 5 districts, namely Bancar, Tambakboyo, Jenu, Tuban and Palang Districts. This regency is also settled on the northern and western end of East Java Province which directly intersects the border of East Java and Central Java. It also has the lowest land point, which is 0 meter above sea level located in Pantura lane, while, the highest one is about 500 meters above sea level located in Grabagan District. In addition, it is also traversed by the Solo River which flows from Solo to Gresik [4].

Tuban has diversities in cultures including but not limited to songs, events, and including the wedding traditions. To cope with music, Tombo Ati song is a popular music in Tuban created by Sunan Bonang hundred years ago that is now relevant to be sang in any religious events in Islam. Another fact related to religious events, an activity called haul is always celebrated during the welcoming Muharram month, the first month in Islam calendar. Last but not the least, sedekah bumi, or so-called as an earth alms, is always held as a form of sending gratitude for the favors gotten from agricultural products.

Based on results by informant . Importantly, in connection with a wedding, local citizens believe that Rajab month, the mid-month of Islam calendar, is a good month for carrying out a wedding ceremony. Because the Prophet said to his people that Rajab is the month of God, Sha'ban is the Prophet's month and Ramadan is the month of his people[5]. Similar to other different regencies' wedding ceremony, it starts with a proposal event, however, in Tuban case, the prospective groom comes to his future wife alone or accompanied by his brother to express his wish addressed to the future bride's parents about to marry their daughter. Afterwards, the prospective bride family comes to the future groom to ask the truth of the proposal. If agreed, then, the day called nggemblok, bringing foods such as rice, side dishes, fruits, sugar, coffee and many more from the groom family to the bride, is further decided. After being given the foods, the bride family shares them to the neighboring families. The reason is because there are several basic essentials humans need to survive such as food, clothing, shelter and medical care; all of these can be found through one of the following subsidizing agencies[6].

\section{B. The Characteristics of a Bridal Dowry in Tuban}

In a traditional Javanese wedding ceremony, there are some traditional ceremonial phases held such as proposal, peningsetan and up to the wedding day. A bridal dowry means of giving something from the prospective groom as a means of engaging the future bride and her family. According to the Javanese ancient tradition, it mainly consists of a set of betel leaves called sirih ayu, pieces of clothes with various motifs, fabric for kebaya (a traditional attire for Indonesian woman), traditional belt called stagen, fruits, groceries (rice, sticky rice, sugar, salt, cooking oil, and kitchen spice), a couple of marriage rings, and some cash as a means of the prospective groom's contribution. That matters based from interview results with informant.

A bridal dowry is usually given either a night before the wedding day, known as midodareni night, or the day of wedding procession [7]. Nowadays, a bridal dowry has transformed a lot from those previous ones, in term of the simplicity and aesthetic values of the packaging. Along with the development of era, moreover, the packaging of a bridal dowry is varied and attractive as it means as a present.

\section{Forms, Functions, and Meaningfulness of a Bridal Dowry in Tuban}

There are subtle differences among the terms "engagement," "betrothal," and "spousal,". The latter two have more legally binding implications for both of the couple, and there is more public ceremony involved in betrothal and spousal( in some cultures, such as Jewish the betrothal is an integral part of the wedding ceremony). However, all three could be private agreement [8]

Based on the results of interviews, nggemblok is one of ceremonial phases, of which means of bringing foods such as rice, fruits, sugar, and coffee. This phase should be passed well as it shows the prospective groom's serious intention of marrying the future bride. Before the date of nggemblok is determined, the prospective groom comes alone or accompanied by his brother to his future bride's home to express his wish of marriage. Then, the prospective bride does the same afterwards to ensure the proposal given by the groom, of which is later known as nggemblok.

Dowry is part of a familial or conjugal fund, which passes down from holder to heir, and usually from the parents to the daughter. It is this part and parcel of the transfer of familial property, but a process of transfer that includes women as well as men, that is male property is transmitted to women as full heirs, semi heirs or residual heirs.[9]

Recently, a bridal dowry has transformed in term of the appearance, from a set of usual packed goods to something more interesting. In accordance with today's trend, a bridal dowry in Tuban also has transformed. The packaging tends to be more varied regarding to who packs the dowry.

First, many bridal dowries have numbers of meaningfulness including in showing that men should responsible for anything women and his future little family needs covering clothing, food, and housing. Generally, there are some goods in the bridal dowry such as a set of prayer equipment as it is compulsory for a Moslem couple. The set of prayer equipment is shaped into different form such as a doll representing bridegroom or any other interesting and unique forms. This type of bridal dowry introduces that Islam is the foundation of future life, yet as a symbol of engaging the couple to God [10].

Second, a set of jewelry such as a ring, necklace, pendant, earring or bracelet, is also important. The amounts are dependable to the prospective groom's ability to afford. To 
make the traditional message of being shiny, thus, it is necessary to consider that the jewels are made from gold or diamond. This jewelry functions as to fulfil the selfactualization and as a means of fulfilling the woman's clothing needs. This dowry type sends the message of meaningfulness that woman should always shine and never be disappointing the future family [10].This process encourages open and honest communication between prospective marriage partners. Composing their own wedding vows and consciously selecting rituals with specific symbolisms in mind also fosters realistic expectations of self, the marriage partner, and the marriage relationship[11].

Third, a set of woman attires includes fabric for kebaya, pieces of clothes with various motifs, working suits, party dresses, pajamas, and other private clothes. All the clothes are packed to be a form of certain familiar animals like peacock and swan. The working attire is folded or rolled, the party dress is folded into a flower shape, pajamas into a squid, and other private clothes into fish or duck. This type of dowry is to fulfill woman's self-actualization and fashion needs. The implicit meaningfulness indicates that both prospective bridegroom should be able to keep their household secrets well [10].

Fourth, based on the results of interview and documentation by informant data showed that a set of makeup may include other body treatment equipment such as soap, body scrub, body lotion, and masker. Those things are arranged as it is in a suitable box or bucket to show beautifulness. This type of dowry functions as maintaining health, beauty, and cleanness of bridegroom's body and face. The meaningfulness of those goods in a bridal dowry is to care the woman's appearance in order to always look beautiful for her husband.

Fifth, a traditional Javanese food comes essential as dealing with a dowry, including but not limited to jenang (usually in a form of sweet soft traditional cake), lemper (a rolled rice filling with flavored shredded chicken), jadah (another form of cake made from rice and is a bit sticky), a layered cake, and many more. In coping with how to pack those foods in a bridal dowry, people usually cut jadah into a shape of rhombus, whereas, jenang and lemper are made by filling in a different unique container. The functions of this type of dowry is to meet the necessity of foods, yet as a symbol of the hope of lifetime togetherness. The meaningfulness of this dowry is to strengthen both family relations so that the bridegroom will live ever after. Because family is one of foundational social institutional in all societies[12].

Sixth, explained by informant that a dowry consisting of fruits such as banana, grape, orange, and apple is arranged based on the fruit types, colors, textures and sizes, into a set of fruit bucket ornamented by beautiful additional ribbons. This type of dowry functions as fulfilling the needs of foods. The meaningfulness of this dowry is it is hoped that the couple will have children who will benefit the nearby people.

Seventh, betel leaves are also included in one of the bridal dowry. The meaningfulness of this dowry type is to hope that the couple will live in a safe and happy life. Eighth, a pair of shoes and sandals are arranged suitable boxes. This dowry functions as fulfilling clothing needs, a complementary to fashion needs. The meaningfulness of this dowry is that the couple can live together happily and always be in a good way. Ninth, the dowry also consists of a bag packed with a beautiful box. This dowry functions as fulfilling the needs of fashion, a complementary to clothes. Its meaningfulness indicates that the man can fulfill the expenses spent during the future life.

The meaningfulness and the philosophy of a bridal dowry indicate that the prospective groom can show his readiness and solidifies his intention of sincerely worshiping to God by going through the married life. The result of the interview shows that a bridal dowry in Tuban includes clothing (proven by the presence of prayer equipment and complete cloth types), food (proven by the presence of fruits, traditional foods, and groceries), and also a jewelry and money. All the dowries are packaged with beautiful, interesting and varied forms and designs, yet without neglecting its important notions [9].

Referring to the results of the study, it is noted that every detail of the bridal dowry has a symbol and meaningfulness. Cassirer refers humans to animal simbolicum, meaning that the culture produced by humans is not always about a real thing, but there is a culture secretly generated or represented by a particular symbolization. Humans never find and know the world and the entire contents without using the help of diverse symbols. Numbers of facts or phenomena exist in the world but they hide the real essences or so-called as noumena. These emerging facts require us to understand and interpret them. Humans do not always directly give a detailed explanation in his life, only a brief symbol delivered. Signs, symbols, icons and codes are the words used to express the noumena or the underlying reality of phenomena . Similarly, the bridal dowry is full of symbols. The bridal dowry given by the prospective groom to the future bride containing clothing, food, jewelry and its accessories is a symbol that men in a married life should be able to prosper his wife and family physically and inwardly. Physical welfare is done by giving sufficient basic needs relevantly to the living standard. Meanwhile, the mental welfare is expected to settle on the men's self for leading the family to any good things and worshiping God. A bridal dowry is not merely a series of social appropriateness, rather, it has a meaningfulness about men's responsibility for further household issues, yet to give protection for his wife and children. The dowry also represents the woman's duty in maintaining the harmony of her family.

\section{CONCLUSION}

A bridal dowry is a symbol of the men's ability and responsibility to fulfill the future bride's needs. The contents of the dowry may vary among different regions in Indonesia based on the cultures and traditions or customs applied. Along with the development of era, many couples recently choose the content of the dowry with useful goods that can be used in daily purposes. This research recommends that a bridal dowry, in this case shown in Tuban Regency, is one cultural heritage needs to preserve to avoid from the extinction and to foster the sense of youth's self-belonging to the country. 


\section{REFERENCES}

[1] D. K. d. I. K. Tuban, "www.tubankab.go.id," Sunday October 2017. [Online]. Available: http//www.tubankab.go.id.np.profil//. [Accessed Monday November 2017].

[2] T. P. J. Timuran, Tuban Bumi Wali: The Spirit Harmony, Surabaya: Badan Perpustakaan dan Kearsipan Prop. Jawa Timur, 2016.

[3] M. Rifa'i, "tubancity.com," Wednesday May 2017. [Online]. Available: http://www.tubancity.com/sejarah-dan-arti-kota-tuban.html. [Accessed Friday June 2017].

[4] D. K. d. I. K. Tuban, "tubankab.go.id," Tuesday July 2017. [Online]. Available: http//tubankab.go.id.np.profil//. [Accessed Sunday August 2017].

[5] Kister. M. J, "Rajab is The Month of God" : A Study in The Persistance of an Earlyy Tradition, $1^{\text {st }}$ Edition, Israel Oriental Studies, 1971, pp. $191-223$
[6] Pierce. Kendra, General Poverty and Situational Proverty, Notebook Entry \#3, Georgetown University, 2013.

[7] Wignjoodipoero, Tata Upacara Perkawinan Jawa, Yogyakarta: Pustaka Intan, 2015.

[8] Monger. George P, An Encycclopedia of Dating Customs and Wedding Traditions, $2^{\text {nd }}$ Edition, ABC-COLIO, 2013, pp. 257

[9] Goody. Jack, and Tambiah.S.J, Bridewealth and Dowry, Cambridge University Press, 1973, pp.17

[10] Soedibyo, Pengantin Indonesia, Upnd Dowryacara Adat Busana dan Tata Rias, Magelang: Tamboer Press, 2014.

[11] Jo Chesser. Barbara."Analysis of wedding rituals ; An Attempt to Make Wedding More Meaningful". National Council on Family Relations. 1980, Vol.29, No.2, pp. 204-209.

[12] Waite. Linda J, Marriage and Family, University of Chicago, 2005, pp. 87-108 